\title{
About Correspondence of Status of a Magistrate under the Provisions of the Russian Constitution and the European Charter on the Statute for J udges
}

\author{
Igor N. Polovtsev
}

Saint-Petersburg State University, Russia

7/ 9 University emb., Saint-Petersburg, 199034

Deputy Head of Building \& Reconstruction Division

E-mail: i.polovtsev@spbu.ru

Abstract. The author herein analyses the status of a magistrate (justice of peace) and his appointment procedure. The author concludes that the procedure for the second and subsequent appointment of the magistrate contradicts the Constitution of Russia and the European Charter on the Statute for J udges (DAJ / DOC (98) 23). The article suggests legal amendments eliminating the discrepancies discovered.

Keywords: magistrate; justice; justice of the peace; lay justice; judicial system; the Constitution of the Russian Federation; guarantees of judge's activity; powers of state authorities; European Charter on the Statute for J udges.

Introduction. In accordance with the Federal Constitutional Law dated December 31, 1996, "On J udicial System of the Russian Federation" [1], federal courts, constitutional (charter) courts and magistrate (justices of peace) of constituent entities of the Russian Federation, constituting the Russian judicial system, shall operate in the Russian Federation.

The federal courts include:

The Constitutional Court of the Russian Federation;

The courts of law: the Supreme Court of the Russian Federation, supreme courts of republics, territorial and regional courts, courts of federal cities, courts of an autonomous region and autonomous districts, district courts, military and specialized courts;

The federal arbitration courts: the Supreme Arbitration Court of the Russian Federation, federal arbitration courts of federal district (arbitration courts of cassation), arbitration courts of appeal, arbitration courts of constituent entities of the Russian Federation and specialized arbitration courts; judges).

Judicial Disciplinary Tribunal (a special judicial authority examining disputes in respect of

The courts of constituent entities of the Russian Federation include: constitutional (charter) courts of constituent entities of the Russian Federation, magistrate (justices of peace) being judges of general jurisdiction of constituent entities of the Russian Federation.

Following the Federal Law "About Magistrate Judges in the Russian Federation" (other translated "On J ustices of Peace in the Russian Federation") [2], magistrate (justices of peace) shall examine:

1) criminal cases related to crimes for committing of which a maximum punishment does not exceed three years of imprisonment;

2) cases on issue of a court order;

3) divorce cases, if there is no dispute about children between spouses;

4) cases on division of property between spouses of jointly acquired property, upon amount of a claim of not more than fifty thousand rubles (RUR 50'000);

5) other cases arising out of family relationships, except for cases on challenging paternity (maternity), establishment of paternity, deprivation of parental rights, restriction of parental rights, child adoption, other cases related to disputes about children and cases on declaring a marriage as null and void;

6) cases on property disputes, except cases on property inheritance and cases arising out of relationships of creation and use of intellectual property results, upon amount of a claim not fifty thousand rubles;

7) cases on determination of property use procedure; 
8) administrative cases attributed to the competence of a justice of peace by the Code of Administrative Offenses of the Russian Federation and the laws of constituent entities of the Russian Federation.

In aggregate, 7,451 judicial districts of justices of peace have currently been established in the territory of the Russian Federation [3].

Revival in the Russian Federation of an institute of magistrate became an unconditional factor of democracy development [4; 5]. Their appearance enabled to decrease the workload on district federal courts. However, there are some shortcomings in the status of a magistrate which can impede the development of this institute the judiciary [6].

Such shortcomings include the principle of periodicity in appointment of justices of peace [7; 8]. It conflicts with the federal and international laws on courts.

Discussion. Pursuant to the Constitution of the Russian Federation, the status of a judge in the Russian Federation is unified [9]. According to Article 119 of the Constitution, the Russian citizens older than 25 years may be judges. They shall have higher legal education and work experience in legal profession of not less than five years. The federal law may impose additional requirements to judges of courts of the Russian Federation. The Constitution of the Russian Federation does not make any distinctions between judges of the federal courts the judges of constituent entities of the Federation. Article 121 of the Constitution of the Russian Federation establishes unified rules for all judges of the courts existing in the Russian Federation. Firstly, judges are irremovable. Secondly, judge's authorities may be terminated or suspended only in the procedure and on the grounds set by the federal law.

Article 28 of the Federal Constitutional Law dated December 31, 1996, "About Judicial System of the Russian Federation" [1] contemplates that authorities and operating procedures of a magistrate shall be determined by the federal law and the law of a constituent entity of the Russian Federation. It should be taken into account that the concepts "term of powers" and "powers of a judge" are different legal concepts. They have different meanings. The Federal Constitutional Law "About J udicial System of the Russian Federation" vests a legislator of a federation constituent entity with the authorities to determine the powers of the magistrate, but not the term thereof.

The same provision ("procedure for appointment (election) and activity of justices of peace shall also be determined by the laws of constituent entities of the Russian Federation") is repeated in Article $1 \S 1$ of the Federal Law dated December 17, 1998, "About Magistrate Judges in the Russian Federation" [2].

Article 7 of the Federal Law "About Magistrate J udges in the Russian Federation" defines the time-limit for powers of a magistrate. The determination of a particular term of powers of the magistrate is referred to a constituent entity of the Russian Federation. The Law established that the magistrate (justice of peace) shall be appointed (or elected) for a term set by the law of the respective constituent entity of the Russian Federation, but for not more than five years. Upon expiry of the said term, a person holding the office of a justice of peace shall be entitled to nominate him-/herself for appointment (election) to such office again. Upon repeated and subsequent appointments (elections) to the office of the justice of peace, the justice of peace shall be appointed (elected) for a term set by the law of the respective constituent entity of the Russian Federation, but for not more than five years.

Meanwhile, Federal Constitutional Law "About J udicial System of the Russian Federation" [1] does not empower a federal legislator (the Federal Assembly of the Russian Federation) to transfer the power to determine the term of office of a magistrate to a regional legislator (the Legislative Assembly of the region).

Proceeding from the provisions of Article 7 Federal Law "About Magistrate J udges in the Russian Federation" [2], a justice of peace shall be appointed on a periodic basis. That is one and the same person shall from time to time go through the procedure of appointment as a magistrate (even upon retaining of the territory in which he/ she carries on his/ her activity). It means that the position of a magistrate is periodically removable, and a justice of peace himself is a periodically removed officer of the judicial system.

Meanwhile, the periodic removability of a judge (a magistrate in this case) violates the principle of irremovability of judges, as enshrined in Article $121 \S 1$ of the Constitution of the Russian Federation [9]. 
It should be also considered that the European Charter on the Statute for J udges (Lisbon, July 10, 1998) [10], even not ratified by the Russian Federation, but introduced into the legal turnover by the Constitutional Court of the Russian Federation [11; 12]. Clause 3.3. of the Charter establishes that where the recruitment procedure provides for a trial period, necessarily short, after nomination to the position of judge but before confirmation on a permanent basis, or where recruitment is made for a limited period capable of renewal, the decision not to make a permanent appointment or not to renew, may only be taken by the independent authority referred to in paragraph 1.3 of the Charter, or on its proposal, or its recommendation or with its agreement or following its opinion. The provisions of Clause 1.4 of the Charter are also applicable to an individual subject to a trial period.

Article 7 § 1 of the Federal Law “About Magistrate J udges in the Russian Federation” [2] can be considered as a trial period referred to in the Charter. In this case after the first appointment a judge shall be repeatedly appointed for an indefinite period (until his/her resignation). It means that Article $7 \S 2$ of the Federal Law "About Magistrate Judges in the Russian Federation" contradicts the constitutional principle of irremovability of judges and the European Charter on the Statute for J udges [10].

A person having taken the office of a magistrate shall be entitled to the guarantees contemplated for all judges by Article $15 \S 5$ of the Russian Law dated J une 26, 1992, 'J udges' status law of the Russian Federation" [13] (other translated "On the Status of J udges in the Russian Federation"). The retired judge shall be paid a pension on the general grounds. The retired judge with a work record in the judge's capacity of no less than 20 years, shall be paid, upon his/her discretion, either a pension on the general grounds or a non-taxable monthly life allowance in the amount of 80 percent of the salary of the judge occupying the corresponding position. For the retired judge with a work record less than 20 years, who has reached the age of 55 (50 for women), the amount of the monthly life maintenance shall be calculated in proportion to the number of full years worked as a judge. For the retired judge with a work record in this capacity of over 20 years, the monthly life maintenance shall be increased based on the following: for every year of the work record over 20 years - one percent of the said maintenance, but, in total, not over 85 percent of the salary of the judge occupying the corresponding position. The retired judges who became disabled as a result of a military injury shall have the right to a monthly life maintenance and to a disability pension.

However, the procedure for periodic appointment (without regard to initial term which may be considered as a trial period) impedes the magistrate to receive the guarantees provided to him/ her by the federal laws. Upon periodic appointment of justices of peace, one cannot disregard the possibility of political and other influence on the procedure for a repeated appointment of a judge. In these conditions the receipt of the guarantees by the judge depends not on his/ her own wishes, experience and quality of fulfillment of job duties, but on other factors. It cannot be recognized as acceptable [14].

Pursuant to Article 71 (o) of the Constitution of the Russian Federation [9], the authorities of the Russian Federation shall include court organization and other issues. According to Article $76 \S$ 1 of the Russian Constitution, among the issues under the jurisdiction of the Russian Federation, federal constitutional laws and federal laws which have direct effect in the whole territory of the Russian Federation shall be adopted.

The issue "personnel of the judicial and law enforcement agencies" (Article $72 \S 1$ (l)) is attributed to joint competence of the Russian Federation and its constituent entities.

The determination of the judges' term of office shall, in accordance with terminology used in the Constitution of the Russian Federation, be referred to the concept of "court organization", but not to "personnel of the judicial and law enforcement agencies", since the question is about legal regulation of general federal status, and of a personal composition of the judiciary.

In view of these provisions, the issue of determination of the term of powers of all judges (including magistrate) shall be made by the federal law (or the federal constitutional law), but not the law of a constituent entity.

It should be emphasized that in respect of all federal courts (the Constitutional Court of the Russian Federation, the Supreme Court of the Russian Federation, the Supreme Court of a republic, district court, military court, the Supreme Arbitration Court of the Russian Federation, the Federal Arbitration Court of a federal district, arbitration court of appeal, arbitration court of a 
federation constituent entity, specialized federal courts) the Federal Constitution Law "About J udicial System of the Russian Federation" [1] specifies three legally important factors which shall be defined by the federal constitutional law: firstly - powers, secondly - establishment procedure, and, thirdly - operation procedure.

As to justices of peace (Article $28 \S 2$ of the Federal Constitution Law "About J udicial System of the Russian Federation"), the establishment procedure, and, accordingly, the term of powers are excluded from the area of regulation of a regional legislator. The following is stated in the law in this respect: powers and operation procedure of a magistrate shall be defined by the federal law and the law of a constituent entity of the Russian Federation. That is the federal legislator is responsible for determination of a term of powers of magistrate, being unified for all constituent entities of the Russian Federation. Thereby, as there is no indication about regulation of this issue by the federal law, it shall be governed by the federal constitutional law.

Conclusions and proposals. Therefore, Article $7 \S 2$ of the Federal Law "About Magistrate J udges in the Russian Federation" [2] conflicts with the federal and international law, and Article 28 of the Federal Constitution Law "About J udicial System of the Russian Federation" [1] shall be modified in terms of specification of a term of powers for a magistrate.

We assume that the stated conflict may be resolved by making the following amendments and supplements to the federal laws.

To add Clause 3 to Article 28 of the Federal Constitution Law "About J udicial System of the Russian Federation" as follows: "3. A magistrate shall be appointed (elected) for a term of three years, whereafter upon positive opinion of the qualification judicial chamber - perpetually".

To restate Article 7 of the Federal Law On Justices of Peace in the Russian Federation as follows: "1. A magistrate (justice of peace) shall appointed (elected) for a term of three years. 2. Upon expiry of the said term, upon positive opinion of the qualification judicial chamber, a person who held the position of a magistrate shall be entitled to nominate him-/ herself for appointment (election) to such office again permanently (until the attainment of an age limit for holding the position of a judge)."

To restate Article $11 \S 3$ of the Russian Law "Judges' status law of the Russian Federation" (other translated "On the Status of J udges in the Russian Federation") as follows: "3. A magistrate shall appointed (elected) for a term of three years. Upon repeated appointment (election), in case of a positive opinion of the qualification judicial chamber, the justice of peace shall appointed (elected) to the same position without limitation of a term of powers until the attainment of an age limit for holding the position of a judge".

The listed amendments will enable to improve the Russian legal system, strengthen the credibility of the judiciary and become the motivation to development of the institute of the magistrate (justices of peace).

\section{References:}

1. About J udicial System of the Russian Federation. Federal Constitutional Law No. 1-FKZ dated December 31, 1996 // Sobranie zakonodatelstva Rossijskoj Federacii [Collection of legislation of the Russian Federation]. 1997. No.1, Article 1; English version available at: URL: http:// www.legislationline.org/documents/action/popup/id/4255 or/and URL: http://cislegislation.com/ document.fwx?rgn=1722 (access of 31.12.2012).

2. About Magistrate Judges in the Russian Federation. Federal Law No. 188-FZ dated December 17, 1998 // Sobranie zakonodatelstva Rossijskoj Federacii [Collection of legislation of the Russian Federation]. 1998. No.51, Article 6270; English version available at: URL: http:// cislegislation.com/document.fwx?rgn=1718 and

URL: http:/ / www.legislationline.org/ documents/ action/ popup/id/ 4369 (access of 31.12.2012).

3. About total number of magistrate judges and quantity of judicial sites in subjects of the Russian Federation. Federal Law No. 218-FZ dated December 29, 1999 // Sobranie zakonodatelstva Rossijskoj Federacii [Collection of legislation of the Russian Federation]. 2000. No.1, Part 1, Article 1; English version available at: URL: http://cislegislation.com/ document.fwx?rgn=12000 (access of 31.12.2012).

4. S.V. Lonskaya. Lay justice. / Kaliningrad. 2000. 215 p. ISBN 5-88874-192-2; Available at: URL: http://law.edu.ru/script/ cntsource.asp?cntID=100088762 (in Russian, access of 31.12.2012). 
5. A.V. Kuzminykh. Revival of J ustice of the Peace in Russia: Possibilities and Experience of Historical Succession // Vestnik Povolzhskoj Akademii Gosudarstvennij Sluzhby [Bulletin of the Povolzhskaya Academy of State Service]. 2010. No.1. p.94-97; Available at: URL: http:// elibrary.ru/item.asp?id=14308448 (in Russian, access of 31.12.2012).

6. O.N. Babayeva. Problematic Issues of Status of J ustices of Peace in the Russian Federation // Vestnik Voronezhskogo Gosudarstvennogo Universiteta [Bulletin of the Voronezh State University]. Series: Pravo. 2007. No.1. p.132-143; Available at: URL: http:// elibrary.ru/item.asp?id=12231723 (in Russian, access of 31.12.2012).

7. R.I. Abushov. The Place of Institute of J ustices of Peace in the Judicial System of the Russian Federation // Vestnik Povolzhskoj Akademii Gosudarstvennij Sluzhby [Bulletin of the Povolzhskaya Academy of State Service]. 2009. No.1(18). p.95-100; Available at: URL: http:// elibrary.ru/item.asp?id=17911854 (in Russian, access of 31.12.2012).

8. I.N. Polovtsev. Justices of Peace - A Problem of Periodic Appointment. // Pravo. Yuridicheskaya Gazeta. 2007. No. 3. p.11-12.

9. The Constitution of the Russian Federation // Sobranie zakonodatelstva Rossijskoj Federacii [Collection of legislation of the Russian Federation]. 2009. No.4, Article 445; English version available at: URL: http://www.constitution.ru/en/10003000-08.htm and (access of 31.12.2012).

10. The European Charter on the Statute for J udges// Rossiyskaya Yustitsiya. 1999. No.7. p.2-4; Russian version available at: URL: http://kaluga.arbitr.ru/law/2366.html; English version available at: URL: https:/ / wcd.coe.int/ViewDoc.jsp?id=1766485 (access of 31.12.2012).

11. In the case concerning the review of constitutionality of certain provisions of Article 15 of the Law of the Russian Federation of 26 June 1992 "On Status of Judges in the Russian Federation", Article 2 of the Federal Law of $21 \mathrm{~J}$ une 1995 "On Amendments to the Law of the Russian Federation "On Status of J udges in the Russian Federation and of Section 1 of Article 7 of the Federal Law of 10 J anuary 1996 "On Additional Guarantees of Social Protection of J udges and Members of Staff of the Courts of the Russian Federation" in connection with complaints of a number of citizens-judges and retired judges. Judgment No. 5-P dated February 19, 2002, of the Constitutional Court of the Russian Federation // Sobranie zakonodatelstva Rossijskoj Federacii [Collection of legislation of the Russian Federation]. 2002. No.10, Article 1015; Available at: URL: http:/ / www.ksrf.ru/ en/ Decision/J udgments/ Pages/ 2002.aspx (access of 31.12.2012)

12. Upon complaint of Ms Yelena Nikolayevna Prishvina against violation of her constitutional rights by para. 1 Article $22 \S 2$ of the Federal Law "On Bodies of J udicial Community in the Russian Federation". Ruling No. 766-O-O dated J une 7, 2011, of the Constitutional Court of the Russian Federation // Sobranie zakonodatelstva Rossijskoj Federacii [Collection of Laws of the Russian Federation]. 2011. No.29. Article.4558; Bulletin of the Constitutional Court of the Russian Federation. 2012. No.1.

13. J udges' status law of the Russian Federation. Russian Law No. 3132-1 dated J une 26, 1992

// Rossiyskaya Yustitsiya. 1995. No.11; English version available at: URL: http:// www.vsrf.ru/ catalog.php?c1=English\&c2=Documents\&c3=\&id=6802 and URL: http:// www.legislationline.org/ documents/ action/ popup/id/ 4369 (access of 31.12.2012).

14. S.A. Semeykina. The Unity of J udicial System and Implementation of Concept of Federal Provision of Activity of J ustices of Peace in the Russian Federation // Uchenye Trudy Rossijsoj Akademii Advakatury I Notariata [Learned Writings of the Russian Academy of Advocacy and Notariate]. 2011. No.2. p.17-23; Available at: URL: http://elibrary.ru/item.asp?id=17311955 (in Russian, access of 31.12.2012). 
УДК 347.995+347.962+342.565

\section{О соответствии статуса мирового судьи положениям Конституции России и Европейской Хартии о статусе судей}

Игорь Николаевич Половцев

Санкт-Петербургский государственный университет, Россия

Университетская наб.д.7/9, Санкт-Петербург, 199034

Заместитель начальника управления капитального строительства и реконструкции

E-mail: i.polovtsev@spbu.ru

Аннотация. В настоящей статье автор анализирует статус мирового судьи и процедуру его назначения. Автор приходит к выводу, что второе и последующее назначение мирового судьи на должность, противоречит Конституции Российской Федерации и Европейской хартии о статусе судей. В статье предлагаются поправки в законодательство, устраняющие выявленные противоречия.

Ключевые слова: мировой судья; мировая юстиция; юридическая система; Конституция Российской Федерации; гарантии независимости судей; компетенция законодательных органов; Европейская хартия о статусе судей. 